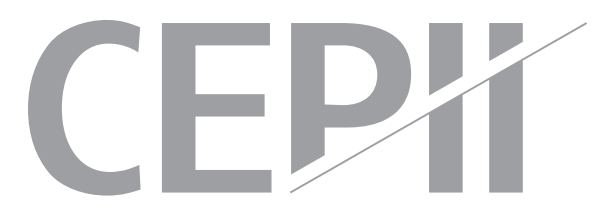

\title{
Variable Trade Costs, Composition Effects, and the Intensive Margin of Trade
}

Lionel Fontagné \& Antoine Berthou

\section{Highlights}

- We estimate the elasticity of extra-EU French firm-level exports with respect a variable trade cost: tariffs.

- A methodology of ratios is controlling for unobserved firm characteristics and for the multilateral resistance terms.

- The elasticity of the product-destination firm-level exports with respect to applied tariffs is estimated at about -2.5 . 


\section{Abstract}

We estimate the elasticity of extra-EU French firm-level exports with respect to applied tariffs -- a variable trade cost. We propose a methodology controlling for unobserved firm characteristics driving selection in exports market and for the resistance terms. Results confirm a significant negative impact of tariffs on firm-level exports, with one fifth of this impact falling on the induced adjustment in the exporters' product mix. When controlling for this adjustment and focusing on the core exported products, the elasticity of the product-destination firm-level exports with respect to applied tariffs is estimated at about -2.5 .

\section{Keywords}

International trade, Firm heterogeneity, Multi-product exporters, Trade elasticity.

I $J E L$

F12, F15.

\section{Working Paper}

\section{CEPI}

CEPII (Centre d'Etudes Prospectives et d'Informations Internationales) is a French institute dedicated to producing independent, policyoriented economic research helpful to understand the international economic environment and challenges in the areas of trade policy, competitiveness, macroeconomics, international finance and growth.
CEPII Working Paper

Contributing to research in international economics

C C CEPII, PARIS, 2015

All rights reserved. Opinions expressed in this publication are those of the author(s) alone.

$\begin{array}{ll}\text { Editorial Director: } & \text { CEPII } \\ \text { Sébastien Jean } & \text { 113, rue de Grenelle } \\ & 75007 \text { Paris } \\ \text { Production: } & +33153685500 \\ \text { Laure Boivin } & \text { www.cepii.fr } \\ \text { No ISSN: 1293-2574 } & \text { Press contact: presse@ }\end{array}$




\title{
Variable Trade Costs, Composition Effects, and the Intensive Margin of Trade ${ }^{1}$
}

\author{
Lionel Fontagné* and Antoine Berthou ${ }^{\dagger}$
}

\section{INTRODUCTION}

Theories of trade with heterogenous firms have provided new channels through which trade openness may affect welfare (Melitz and Redding, 2013). In this class of models, changes in variable trade costs are predicted to modify the microeconomic composition of aggregate trade flows between countries through firm-selection (Melitz, 2003; Chaney, 2008), or within-firm product selection (Eckel and Neary, 2010; Bernard et al., 2011; Arkolakis and Muendler, 2010; Mayer et al., 2014), which affects the average value of exports per transaction. ${ }^{2}$ Estimating the elasticity of firm-level exports with respect to variable trade costs, a key parameter of these models, requires controlling for these compositional effects.

Our objective is to provide an estimation of the effect of variable trade costs on firm-level exports. Data collected by the French customs on the value of firm-level exports by product, destination and year, are combined with applied tariffs faced by French exporters in each destination and for each product. ${ }^{3}$ Variation in tariffs is used to identify the impact of variable trade costs on the margins of French aggregate exports, and on the margins of firm-level exports.

We start by illustrating how microeconomic composition effects shape aggregate exports, by estimating a simple gravity equation on the margins of aggregate French exports. We show that variable trade costs have no significant effect on the mean value of transactions while negatively impacting their number. This confirms theoretical predictions on the selection of firms and/or products within firms affecting the microeconomic composition of aggregate exports.

Against this background, we estimate the elasticity of firm-level exports with respect to variable trade costs, using a methodology of ratios that corrects for firm characteristics driving selection in exports market and the value of shipments, and the resistance term specific to each destination. The implementation of our empirical strategy requires choosing a benchmark market and a benchmark population of exporters in each destination. We take as a reference the US market - the most frequent destination for French exporters outside the EU - and the top 500 exporters in each destination.

The estimations are performed by pooling information about firm-level exports and tariffs for three years: 2001, 2004 and 2007. Over these years, most of the variance in applied tariffs faced by French exporters is coming from the cross-sectional dimension of the panel. Results confirm a significant negative impact of tariffs on firm-level exports, with an elasticity of about -2 . About one fifth of this impact is due to firms adjusting their product mix in more protectionist destinations. Accordingly the elasticity of the average firm-level exports per product (about -1.7) is potentially subject to composition effects related to changes in the product mix by firms across destinations.

\footnotetext{
${ }^{1}$ We thank participants to the CEPII seminar for helpful comments. Lionel Fontagné acknowledges support from the Banque de France. We thank Houssein Guimbard for providing tariff data at the country-product level. This article does not reflect the views of the Banque de France.

* Paris School of Economics (University Paris 1) and CEPII. Corresponding author, ()

${ }^{\dagger}$ Banque de France and CEPII. Email: antoine.berthou@banque-france.fr, ()

${ }^{2}$ In the following, transaction is defined as export flow by firm $f$ of product $p$ to destination $j$.

${ }^{3}$ Recall that applied tariff can be inferior to bound tariffs in presence of a binding-overhang. Also, applied tariffs may differ by exporter-importer pair for a given product, due to preferences possibly conceded by the importer. We rely on MAcMap tariff data at the HS6 level, faced by French exports, taking care of endogeneity of tariffs to export structures (Bouet et al., 2008).
} 
We tackle the issue of the changes in the composition of the product mix by using firm-level exports per product and destination. When properly controlling for product composition and focusing on the core exported products, the elasticity of the product-destination firm-level exports is estimated at about -2.5.

These results add to our understanding of the impact of trade costs on the margins of exports. Former studies focusing on the role of geographical distance (Lawless, 2010; Crozet and Koenig, 2010) found no effect of distance on the mean value of exports per shipment. Using US data, Bernard et al. (2011) showed that distance is sorting exported products on the top of sorting exporters. ${ }^{4}$ One important issue can be raised though, related to the nature of trade costs, as geographical distance may be related to both fixed and variable trade costs (Anderson and van Wincoop, 2004)..$^{5}$ The distinction between variable and fixed costs is of utmost importance in an heterogenous firms settings, as fixed costs are expected to impact differently trade margins. In contrast, changes in tariffs can be confidently interpreted as changes in the variable costs, and can be used to estimate the variable trade costs elasticity.

We are not the first to examine the impact of tariffs on the margins of trade. Baldwin and Gu (2004) examine how bilateral tariff cuts between the US and Canada led to changes in export participation of Canadian plants (with no product dimension). Buono and Lalanne (2012) estimate the impact of the tariff reductions associated with the Uruguay Round (at the sectoral level) on trade margins for the French firms (with no product dimension either). Iacovone and Javorcik (2010) use the change in US tariffs on Mexican exports to identify an impact on product churning within industries. Bernard et al. (2011) examine how changes in tariffs associated with the Canada-US Free Trade Agreement impacted the number of goods produced by US domestic firms. Fitzgerald and Haller (2014) use Irish firm-level exports data and show that relying on micro-level estimations is key to understand the aggregate response of trade to changes in real exchange rates or tariffs. Bas and Bombarda (2011) analyze the effects of Chinese trade liberalization on French exporters. Using similar export data for France combined with firm-level Chinese exports data, Bas et al. (2014) show that when the firm productivity distribution is log-normal, the elasticity of aggregate exports becomes heterogenous across country pairs due to a supply-side effect.

Our strategy does not rely on a specific trade liberalization episode, but rather provides a systematic analysis of the relationship between the variations in tariffs and firm-level exports, e.g. the microeconomic elasticity of exports with respect to variable trade costs variations. Most importantly, we warn against the bias in the intensive margin defined at a higher level of aggregation (country-level exports) due to firm and product composition effects. We use a strategy that controls for firm-level unobserved characteristics and destination-specific resistance terms. We end-up with an estimation of the elasticity of firm-level exports with respect to variable trade costs - one minus the constant elasticity of substitution in Melitz (2003) or Chaney (2008) - that can be used to calibrate models and simulate the impact of trade liberalization on welfare. Interestingly, our strategy can be replicated using any firm-level exports dataset for a single exporting country by destination and product, as it does not require any additional firm-level information.

The rest of the paper is organized as follows. In Section 1, we show how the recent literature on trade models with heterogenous firms provides guidelines for the empirical analysis. In Section 2, we present the French customs data as well as tariff data. In Section 3, we propose a first decomposition of the aggregate value of French exports in each destination and estimate the impact of tariffs on these margins of aggregate French exports. In Section 4, we propose an alternative decomposition of trade margins in order to provide an estimation of the elasticity of firm-level exports to applied tariffs, controlling for firm composition effects. In Section 5 we finally control for product composition effects. The last section concludes.

\footnotetext{
${ }^{4}$ Berthou and Fontagné (2013) show that changes in the number of products exported was an important margin of adjustment for French exporters consecutive to the euro adoption.

${ }^{5}$ Albornoz et al. (2013) provide evidence showing that survival probability declines with geographical distance, consistent with distance being mostly affect by fixed rather than sunk cost according to their model.
} 


\section{Theoretical Motivation}

New New trade theories have been exploring over the past fifteen years the welfare consequences of trade liberalization in presence of single-product firms differing in their overall production efficiency (Melitz, 2003; Chaney, 2008), or of multi-product firms having different product capability (Bernard et al., 2011). In the first class of models, a reduction in variable trade costs leads to aggregate productivity and welfare gains through the selection of firms, while the second class of models adds one product selection margin, within the firm.

The estimation of the variable trade costs elasticity with respect to the mean value of transactions is affected by changes in the firm and product composition of exports. A decline in the variable trade costs increases the value of firm exports, but the entry in the export market of competitors with smaller export values reduces the average value of firm-level exports (Melitz, 2003). With firm-level productivity following a Pareto distribution however, these two effects cancel-out and the average value of exports per firm remains unaffected (Bernard et al., 2012).

In presence of multi-product exporters, variable trade cost also lead to within-firms product selection: the product mix of exporters adjusts endogenously. The effect of variable trade costs on the average value of firm-level exports per product becomes ambiguous due to the presence of product composition effects (Bernard et al., 2011).

Accordingly, the estimation of the elasticity of the intensive margin of country-level exports (average exports per firm-product in customs data) with respect to variable trade costs must account for the existence of firm and product composition effects. Below we propose an empirical strategy addressing this issue, using French firm-level customs data. It allows controlling for firm - or firm-product - composition effects. We end-up with an estimation of the value of the microeconomic trade elasticities.

\section{CUSTOMS AND TARIFFS DATA}

The analysis relies on a panel of the French customs data, which comprises the universe of individual French firms' reporting their annual export flows. ${ }^{6}$ The source data has a firm-destination-product dimension, identified by a firm identifier (SIREN), a destination code (ISO) and a product category that uses the Combined Nomenclature with 8 digits (CN8). The trade data are then aggregated using the 6-digit Harmonized System (HS6) classification in the 1992 revision. This ensures that the product mix of exporters is not affected by changes in product classification over time. ${ }^{7}$ All products potentially exported by the firm (including agriculture) are included. After aggregation of the products into the HS6 classification, each observation corresponds to the value of exports by firm $(f)$ in product category $(p)$ to destination $(j)$ in year $(t)$, which we note $x_{f p j t}$.

Tariff data are provided for the years 2001, 2004 and 2007 by the MAcMaps database at the HS6 level. From this data we only keep information about the applied tariffs faced by French exporters. All details are provided in the Appendix Section. The empirical analysis will therefore only rely on these three years, and will use the cross-sectional dimension of the data as applied tariff variations over time are limited. The set of destinations is also restricted to non-EU15 destinations for two reasons: firstly, French exporters not only face no tariff duties within the Single market but also benefit from removed non-tariff barriers; secondly, a reporting threshold is used for intra-EU trade flows, and small exporters are absent from the data. Extra-EU, in contrast, the reporting threshold for exports is set to only 1,000 euros per transaction. Our baseline unit of observation is the tariff duty applied to imports from France in destination $j$, for product $p, \tau_{j p} .{ }^{8}$ Importantly, we compute the average tariff faced by each individual exporter in each of

\footnotetext{
${ }^{6}$ French custom data was also used in Eaton et al. (2004) and several other papers recently.

${ }^{7}$ We thank one anonymous referee for suggesting this control.

${ }^{8}$ For sake of simplicity, the subscript $t$ for years is implicit.
} 
the destinations $\left(\tau_{f j}\right)$ using firm-specific weights for each product (the product dimension of the tariff accordingly disappears). Finally, we compute the mean applied tariff faced by aggregate French exports in each of its destinations $\left(\tau_{j}\right)$ using France-specific weights for each product. These three measures of tariffs will be used in the different specifications of our econometric exercise: $\tau_{j}$ will be used to assess the impact of tariffs on the margins of aggregate exports; $\tau_{f j}$ and $\tau_{j p}$ will be respectively used in the firm level and firm-product level estimations. Notice that we will used a transformation of the two latter. Details regarding the data sources for tariffs and the construction of these variables are provided in the Appendix Sections 6.1 and 6.2.

Descriptive statistics regarding the three tariff measures are provided in Table 1. The average tariff faced by French exports in extra-EU destinations is about 10\%, whatever the metric (average of HS6 tariffs, firm-level or France-level tariffs), with a standard deviation of about $17 \%$ across destinations in the case of the HS6 tariffs. Importantly, we observe tariff peaks of 50\% for destination-products in the top percentile, while about $25 \%$ of the HS6 destination-products face no tariffs. Taking simple average of tariffs in each destination, the most protectionist destinations appear to be the Salomon Islands (36\%) or the Bahamas $(30 \%)$ with also large emerging economies among the top protectionists countries (Egypt, 25\%, Nigeria, $24 \%$, India, 23\%). No tariff was applied to French exporters in destinations that were about to enter (or entered) the European Union during 2001-2007 period.

Importantly, the variation of tariffs over the period is quite limited. This implies that most of the variance for the estimation of the trade elasticities with respect to variable trade costs will come from the cross section of countries and products, rather than from the time changes of tariffs. This empirical evidence suggests two alternative empirical strategies to assessing the elasticity of exports with respect to tariffs: either use a specific liberalization episode (e.g. the NAFTA, the Chinese accession into the WTO) and take benefit of the time variation in the tariffs faced by firms, or alternatively focus on the cross-sectional variation in tariffs. While the first approach authorizes to control for unobservable multilateral resistance terms using fixed effects, it is difficult to isolate the potential impact of other determinants (e.g. commitment to trade disciplines imposed by the WTO or regional agreements). While the second approach imposes a specific empirical strategy to control for multilateral resistance terms (see below), it authorizes a more-embracing diagnosis on the impact of tariffs, beyond specific liberalization episodes. We embark on the second approach.

\section{IMPACT OF TARIFFS ON AGGREGATE TRADE MARGINS}

A first decomposition of the aggregate value of French exports, in each destination, illustrates how firm and product selection can affect the intensive margin of aggregate exports. The baseline unit of observation of our data corresponds to the value of exports by firm $(f)$ of product $(p)$ to destination $(j)$ in year $(t)$, which we note $x_{f p j}$, omitting $t$ for the sake of simplicity. The sum of these individual trade flows ("transactions" thereafter), over firms and products, is the value of aggregate French exports to a destination in a given year: $X_{j}{ }^{9}$ We propose here two decompositions of this aggregate value. ${ }^{10}$

In this first decomposition (Equation 1), the aggregate value of French exports to a destination $j$ can be expressed as the product of the number of transactions $\left(N_{j}^{f p}\right)$ and the average value of exports per firmproduct $\left(\bar{X}_{j}^{f p}=\frac{\sum_{f p} x_{f p j}}{N_{j}^{f p}}\right)$. In this case, the intensive margin is affected by the composition of firms

\footnotetext{
${ }^{9}$ In the notations the country of origin is indeed omitted since the data only cover French exports.

${ }^{10}$ In the following we use capital letters for variables observed at the aggregated level. The subscripts are for the level of aggregation and the exponent the dimension(s) on which the aggregation was done. For instance, $N_{j}^{f p}$ is a count at the aggregate level of the number of the firm-products ( $f p$ in exponent) on destination $j$ (subscript).
} 
Table 1 - Descriptive statistics : average tariffs faced by French exports (2001, 2004 and 2007)

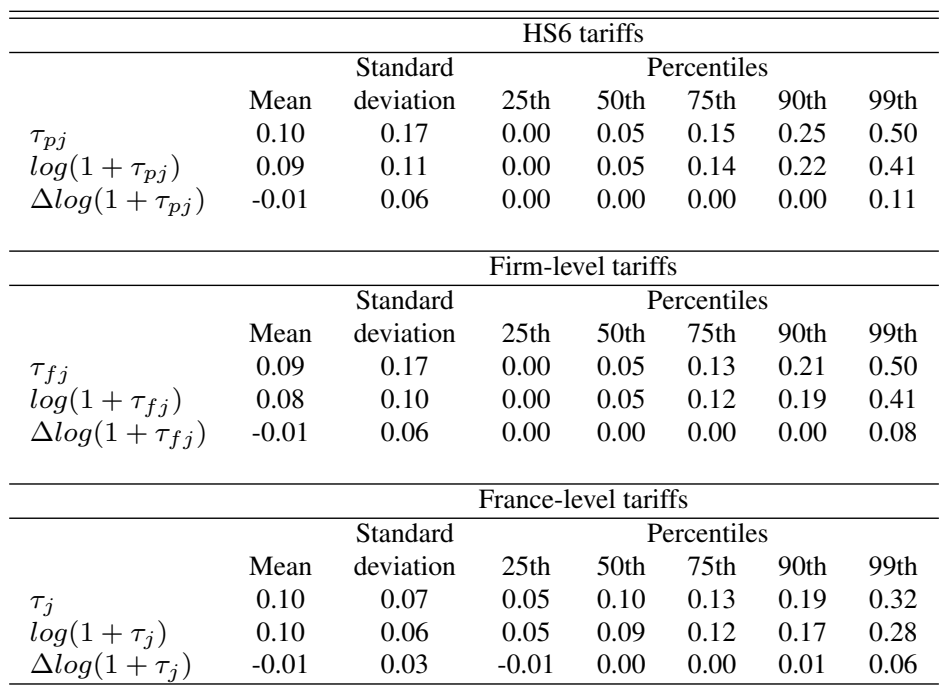

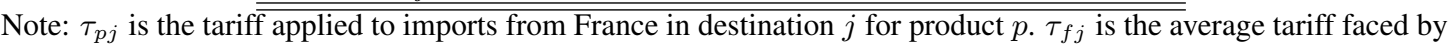
firm $f$ in destination $j . \tau_{j}$ is the average tariffs faced by French exports in destination $j$. Years are pooled. Variations are observed between two years, i.e. 2001-2004 and 2004-2007.

and products in each destination.

$$
X_{j}=N_{j}^{f p} \times \bar{X}_{j}^{f p}
$$

Starting form this decomposition, we can provide an estimation of the impact of applied tariffs on the margins of aggregate French exports.

We estimate a gravity-like equation (Equation 2) using Ordinary Least Squares (OLS), where the dependent variable $Y_{j t}^{f p}$ is either the number of transactions to each destination $\left(N_{j t}^{f p}\right)$ or the mean value per transaction $\left(\bar{X}_{j t}^{f p}\right)$, as reported in Equation 1. Our main variable of interest is the weighted average of tariffs applied to products of French origin in each destination $\left(\tau_{j t}\right)$. The weight applied for each product category corresponds to its share in French total exports in the first years of the sample (2000-2001). These weights can be therefore considered as exogenous, since they are neither affected by the characteristics of the destination, nor by the tariffs applied by that destination. All the details of the construction of tariffs applied to French exports are provided in the Appendix section.

$$
\ln \left(Y_{j t}^{f p}\right)=\mu_{0}+\mu_{1} \ln \left(G D P_{j t}\right)+\mu_{2} \ln \left(1+\tau_{j}\right)+\mu_{3} \ln \left(\Omega_{j}\right)+\kappa_{t}+\epsilon_{j t}
$$

$G D P_{j t}$ is the real GDP of the destination. $\Omega_{j}$ is a set of variables controlling for other dimensions of market access: the geographic distance between France and the destination, the area of the destination in squared kilometers (a larger area, everything equal, means more dispersed demand), a dummy indicating whether it is landlocked or not, a dummy indicating whether the country is contiguous to France, a dummy indicating whether the population in $j$ speaks French, and a dummy indicating whether the destination had a colonial link with France. ${ }^{11} \kappa_{t}$ is a set of time dummies. $\epsilon_{j t}$ is the error term. As discussed above,

\footnotetext{
${ }^{11}$ Switzerland is the only non-EU country contiguous to France. These data are provided by the CEPII in the Distance database. Data for real GDP are from the Penn World Tables. Tariff data comes from MAcMap-HS6.
} 
most of the variance in tariff used to identify the trade elasticity comes from the cross-sectional variation of the tariffs.

Estimating elasticities in this gravity framework requires accounting for the multilateral resistance terms (Anderson and van Wincoop, 2003). However, given that the tariff data we use has a destination $\times$ year dimension, using country fixed effects would control for most of the variance in the tariff (as discussed above, most of the variance in tariffs is cross-sectional). We consequently start by providing a first set of estimates without controlling for resistance terms. In a second step, we introduce additional controls that aim at (although imperfectly) controlling for these resistance terms and the competitive environment in each destination: the multilateral distance of each destination vis-à-vis the rest of the world (weighted by trade partners GDP's) and the Herfindahl index capturing the concentration of imports over the set of trade partners.

The results from the estimation of Equation 2 reported in Table 2 show that variable trade costs (measured by tariffs) have a strong negative impact on the number of transactions, with no significant impact on the intensive margin. ${ }^{12}$ This result is confirmed when we control for the multilateral distance of the destination vis-à-vis the rest the world and for the Herfindahl index in columns (4), (5) and (6). ${ }^{13}$ In our preferred estimate (column 6), the elasticity of aggregate trade with respect to variable trade costs is about -3 , which is fully captured by the adjustment along the extensive margin. ${ }^{14}$

Table 2 - Influence of tariffs on country-level export margins

\begin{tabular}{|c|c|c|c|c|c|c|}
\hline Dep. Var. & $\begin{array}{c}(1) \\
\log N_{j t}^{f p} \\
\end{array}$ & $\begin{array}{c}(2) \\
\log \left(\bar{X}_{j t}^{f p}\right)\end{array}$ & $\begin{array}{c}(3) \\
\log \left(X_{j t}\right) \\
\end{array}$ & $\begin{array}{c}(4) \\
\log N_{j t}^{f p} \\
\end{array}$ & $\begin{array}{c}(5) \\
\log \left(\bar{X}_{j t}^{f p}\right)\end{array}$ & $\begin{array}{c}(6) \\
\log \left(X_{j t}\right) \\
\end{array}$ \\
\hline $\log \left(1+\tau_{j t}\right)$ & $\begin{array}{r}-3.928^{a} \\
(0.639)\end{array}$ & $\begin{array}{c}0.726 \\
(0.562)\end{array}$ & $\begin{array}{l}-3.202^{a} \\
(0.766)\end{array}$ & $\begin{array}{r}-3.683^{a} \\
(0.631)\end{array}$ & $\begin{array}{c}0.613 \\
(0.589)\end{array}$ & $\begin{array}{l}-3.070^{a} \\
(0.778)\end{array}$ \\
\hline Time dummies & yes & yes & yes & yes & yes & yes \\
\hline Control for multilateral resistance & no & no & no & yes & yes & yes \\
\hline Control for import concentration & no & no & no & yes & yes & yes \\
\hline Observations & 240 & 240 & 240 & 240 & 240 & 240 \\
\hline R-squared & 0.761 & 0.608 & 0.769 & 0.789 & 0.610 & 0.783 \\
\hline
\end{tabular}

Note: Significance levels: ${ }^{c} 10 \%,{ }^{b} 5 \%,{ }^{a} 1 \%$. Robust standard errors in parentheses. $N_{j t}^{f p}$ is the number of firm-product transactions to destination $j$. $\bar{X}_{j t}^{f p}$ is the mean value of firm-product transactions to destination $j . X_{j t}$ is the aggregate value of exports to destination $j . \tau_{j t}$ is the tariff applied to the imports of goods from France in year $t$ (construction detailed in Appendix). Sample: Extra EU 15 destinations; pooled data for years 2001,2004 and 2007. Detailed results are provided in Table ST2 in Appendix.

This result is in line with the predictions obtained from a model of trade with heterogenous firms as in Melitz (2003) or Chaney (2008) under the assumption that firm-level productivity within each sector follows a pareto distribution: firm entry is expected to fully compensate the negative impact of variable trade costs on firm-level exports, which leaves average exports per firm unaffected due to a composition effect. In the section below, we rely rather on firm-level estimations, or firm-product estimations, in order to accurately estimate trade elasticities on the firm (or firm-product) intensive margins.

\footnotetext{
${ }^{12}$ As the two margins in logs are a linear combination of total exports, the elasticity of each margin with respect to tariffs adds up and reflects the elasticity of aggregate exports with respect to this variable cost: $\frac{\partial \ln \left(X_{j}\right)}{\partial \ln \left(1+\tau_{j}\right)}=\frac{\partial \ln \left(N_{j}^{f p}\right)}{\partial \ln \left(1+\tau_{j}\right)}+\frac{\partial \ln \left(\bar{X}_{j}^{f p}\right)}{\partial \ln \left(1+\tau_{j}\right)}$.

${ }^{13}$ We thank one anonymous referee for suggesting the inclusion of the Herfindahl index as a control in this estimation.

${ }^{14}$ The coefficients on the control variables in the aggregate exports estimation (column 6) are in line with what is generally expected in the trade and gravity literature: WTO membership (non-significant), distance (-), country size (-), landlocked (-), common language (+), colonial link (+), common legal origin (non-significant), GDP (+), multilateral distance (+), Herfindahl index (-).
} 


\section{IMPACT OF TARIFFS ON FIRM-LEVEL TRADE MARGINS}

In this section, we propose an alternative decomposition of aggregate exports that will be used to assess the impact of variable trade costs on firm-level trade margins. Considering each destination, we start from total exports and compute the number of products and the mean value of product exports by firm. We then estimate the impact of tariffs on each of these three variables, using an original identification strategy that controls for multilateral resistance terms and for firm-level unobserved characteristics affecting their selection in destination markets.

\subsection{Firm-level decomposition of aggregate exports}

In our decomposition of firm-level exports, presented in Equation 3, we rely on the observed value of exports at the firm-level, rather than the average value of exports at country level (as in Equation 1). This ensures that the intensive margin is not biased due to firm selection. Aggregate exports to a destination $j$ is the sum of firms' exports to this destination $\left(x_{f j}\right)$, which can be decomposed into the number of products exported by each firm $\left(n_{f j}^{p}\right)$, times the mean value of product exports by firm $\left(\bar{x}_{f j}^{p}=\frac{\sum_{f} x_{f p j}}{n_{f j}^{p}}\right)$. Accordingly, theory predicts an ambiguous effect of the variable trade costs on the average value per transaction in each destination. Recall that using such decomposition the intensive margins remains affected by the composition of products within each firm.

$$
X_{j}=\sum_{f} x_{f j}=\sum_{f} n_{f j}^{p} \times \bar{x}_{f j}^{p}
$$

We show in Table 3 a series of descriptive statistics regarding the average number of exporters in each destination, and firm-level exports per destination (number of products, mean value of product exports by firm and total exports to the destination).

The first column shows high variance in the number of firms exporting to a destination. Considering extraEU15 destinations, only 577 firms export in the less popular destinations (first quartile), while 13,278 firms export in the most popular ones (in the last percentile). ${ }^{15}$ The second column reports the number of products exported by firm in each destination: about half of firm-destination observations relate to firms exporting a single product in each destination. Hence the product selection is potentially playing a role for the other half of French exporters. The distribution of products across firm-destination observations is highly skewed: firm-destinations in the top decile report 5 products or more, and 20 products in the top 1 percentile.

\subsection{Empirical strategy}

We now rely on firm-level estimations with an empirical strategy that controls for firm-level unobserved characteristics affecting their selection into exports markets (such as productivity or product quality). We also properly control for multilateral resistance terms in each destination. This empirical strategy based on a transformation of the firm-level exports variable is expected to deliver unbiased estimations of the impact of variable trade costs on exports.

In the context of a trade model with heterogenous firms with CES preferences and multiple destinations as in Chaney (2008), the exports of a firm $f$ exporting (in a certain sector) to destination $j$ can be expressed

\footnotetext{
${ }^{15}$ This result is in line with previous findings by Eaton et al. (2004) who show that most French exporters export to a limited number of destinations.
} 
Table 3 - Firm-level exports margins to non-EU15 destinations

\begin{tabular}{|c|c|c|c|c|}
\hline \multicolumn{5}{|c|}{ Total number of exporters over the period 2000-2002 is 100,358 (extra-EU destinations) } \\
\hline & \multirow{2}{*}{$\begin{array}{c}\text { Number of exporters } \\
\text { by destination } \mathrm{j}\end{array}$} & \multicolumn{3}{|c|}{ Firm-level exports to each destination $\mathrm{j}$} \\
\hline & & $\begin{array}{c}\text { Number of products } \\
n_{f j}^{p}\end{array}$ & $\begin{array}{c}\text { Mean exports per product } \\
\bar{x}_{f j}^{p}\end{array}$ & $\begin{array}{c}\text { Total exports } \\
x_{f j}\end{array}$ \\
\hline Mean & 4,430 & 2.5 & 115.0 & 413.4 \\
\hline Standard deviation & $5,632.5$ & 6.3 & $4,038.4$ & $9,465.7$ \\
\hline 1st quartile & 577 & 1 & 3.6 & 4.7 \\
\hline Median & 1,989 & 1 & 10.9 & 17.9 \\
\hline 3rd quartile & 5,813 & 2 & 39.4 & 83.3 \\
\hline 9th decile & 11,112 & 5 & 141.7 & 376.9 \\
\hline 99th percentile & 13,278 & 20 & $1,435.8$ & $5,568.6$ \\
\hline
\end{tabular}

Source: French customs. Export values are expressed in thousands of euros. $f$ stands for the firm, $j$ for the destination, $p$ for the product.

as follows:

$$
x_{f j}=\frac{\left(\pi_{f} \theta_{f j}\right)^{1-\sigma}}{P_{j}^{1-\sigma}} \mu Y_{j}
$$

$x_{f j}$ is firm-level exports to destination $j, \mu Y_{j}$ is the demand for the differentiated goods in that destination, $\pi_{f}$ is the firm's f.o.b. price, $\theta_{f j}=1+\tau_{f j}$ is an iceberg variable trade cost (the power of the firmspecific average ad valorem tariff), $P_{j}$ is the price index, and $\sigma$ the elasticity of substitution. In order to correctly estimate the trade elasticity, we therefore need to control for the firm-level price and market characteristics, both of them being unobserved.

We rely on a transformation of the exports variable $x_{f j}$, using a benchmark destination for the firm $f$, and a reference population of firms exporting to destination $j .{ }^{16}$ This strategy requires making use of a frequent market for French exporters among extra-EU destinations, in order to keep the largest number of firms in the sample used for the estimations. Outside of the European Union, the first market for French exporters is the United States. We therefore use in our estimations the US as the benchmark destination for French exporters (thus only keeping in-sample those firms having positive exports in year $t$ to this destination). Taking the ratio of firm-level exports to destination $j$ to the same firm's export to the US in the same year, we obtain the following expression where the firm-level f.o.b. price $\pi$ (function of the unobserved productivity of the firm) has disappeared: ${ }^{17}$

$$
\frac{x_{f j}}{x_{f u s}}=\left(\frac{\theta_{f j}}{\theta_{f u s}}\right)^{1-\sigma} \frac{Y_{j} P_{j}^{\sigma-1}}{Y_{u s} P_{u s}^{\sigma-1}}
$$

To eliminate the aggregate market conditions in each destination, we make use of a reference population of firms for which we compute a similar ratio as the one presented in Equation 5. Our reference is the average population of French exporters in each market, where $\bar{x}_{f j}$ refers to the mean value of firm-level

\footnotetext{
${ }^{16}$ The method of ratios implemented here is comparable to the one in Bas et al. (2014), where the reference population of firms is a sample of Chinese exporters. Our strategy rather uses the average population of French firms in the sample exporting to the same destination $j$. We make the assumption of identical preferences: $\mu$ has no country dimension.

${ }^{17}$ We follow the usual assumptions of identical preferences
} 
exports by French companies in destination $\mathrm{j}$ for a given year, and $\bar{x}_{f u s}$ is the mean value of export in the US market for the same year. ${ }^{18}$

Taking the ratio of these two ratios, we get rid of the market conditions (price index and demand shifter) and we obtain the expression reported in Equation 6, where the relative exports of a firm is expressed as a function of the relative tariffs that she faces in each market:

$$
\widetilde{x_{f j}} \equiv \frac{x_{f j} / x_{f u s}}{\overline{x_{f j}} / \overline{x_{f u s}}}=\left(\frac{\theta_{f j} / \theta_{f u s}}{\overline{\theta_{f j}} / \overline{\theta_{f u s}}}\right)^{1-\sigma} \equiv{\widetilde{\theta_{f j}}}^{1-\sigma}
$$

This transformation fully exploits the cross-sectional variation in firm-level exports and tariffs. In this case, all the variance in the data that we exploit comes from the heterogeneity in tariffs across destinations and firms. With this strategy, we identify the effect of tariffs variations relative to the US for a given firm, relative to a different French exporter that would face different tariffs on average in each market. All the heterogeneity in terms of tariffs across firms in this case is related to the differences in their product mix, which exposes them to different variable trade costs in each destination. We will tackle this issue in the next section.

The computation of the ratios requires observing the same firm in several destinations. Also, a sufficiently large number of firms must be observed in the reference destination (the United States in our case) and in the destination country $j$. For this reason, we apply the following filters on the raw data before implementing the above strategy:

- Exporters. We rely on the sample of the top 500 French exporters in the US (the top 500 French firms with the largest market share in French total exports to the U.S.), exporting to at least 3 destinations in each year. This allows us to make sure that the firm will be observed both in the benchmark destination (the United States) and in other destinations where we want to evaluate the impact of tariffs. ${ }^{19}$

- Reference population. The reference population is constituted by the top 500 French firms exporting to each destination, including the US. As a robustness, we construct a ratio where the reference populations in the U.S. and in destination $j$ are identical. ${ }^{20}$.

- Destination countries. While we only keep extra EU15 countries in the sample, we also focus on the most popular destinations for French exporters outside of the EU, by keeping only those destinations where on average more than 1,000 French firms operate through exports every year. We end-up with 30 destinations that we report in Appendix Table ST1.

\subsection{Micro estimates: firm-level exports}

We log-linearized Equation 6 (see Equation 7). We estimate this relation with Ordinary Least Squares (OLS) to get a prediction for the trade elasticity $(1-\sigma)$. As shown in the previous section, the method of ratios controls for the characteristics of the firm and the destination. All the variance comes from the variation of tariffs and exports across firms-and-destinations. We also replicate this estimation by taking as the dependent variable a transformation of the number of products exported by the firm $\left(\log \widetilde{n}_{f j t}^{p}\right)$ and

\footnotetext{
${ }^{18}$ Note that one gets rid of the relative price parameter in each market iff the average population of firms in $j$ and in the US has the same average productivity. In the case where the two populations do not share the same productivity, the ratio expression has an additional parameter $\frac{\Phi_{j}}{\Phi_{u} s}$ reflecting the ratio of the average productivity in each market, which accounts for firm selection as a Mills ratio in a Heckman selection model. This term is unobservable but highly correlated to distance.

${ }^{19}$ Thus, French firms not exporting to the U.S. are excluded.

${ }^{20}$ This ensures that the estimation is not affected by firm selection, which would imply that the two reference populations have different average productivity
} 
the transformation of the average value of firm-level exports per product $\left(\widetilde{\log }_{f j t}^{p}\right)$.

$$
\log \left(\widetilde{x_{f j t}}\right)=(1-\sigma) \log \left(\widetilde{\theta_{f j t}}\right)+\epsilon_{f j t}
$$

Estimation results reported in Table 4 show that in all specifications, variable trade costs have a negative impact on firm-level exports. In our preferred specification where we rely on a single reference population in the US and in the destination country (column 1, panel 2), the estimated elasticity is about -2 and is highly significant. This elasticity is larger $(-2.47)$ when the estimation relies on the population of the top 200 exporters in the United States (column 4, panel 2). The estimated coefficients reported in Table 4 also confirm that these results are not much affected by the choice of the weighting of products in the construction of the tariff variable, or by the choice of the reference population.

Importantly, the results also indicate that variable trade costs impact both the firm-level average exports per product and the number of product exported: tariff affect the product mix of firm-level exports. In our preferred specification, about $17 \%$ of the effect of variable trade costs is reflected in the number of products exported, and the rest of the effect is channeled through the intensive margin.

Table 4 - The effect of tariffs on firm-level export margins

\begin{tabular}{|c|c|c|c|c|c|c|}
\hline & (1) & (2) & (3) & (4) & $(5)$ & (6) \\
\hline Dep. Var. & $\log \widetilde{x}_{f j t}$ & $\log \widetilde{n}_{f j t}^{p}$ & $\log \widetilde{\bar{x}}_{f j t}^{p}$ & $\log \widetilde{x}_{f j t}$ & $\log \widetilde{n}_{f j t}^{p}$ & $\log \widetilde{\bar{x}}_{f j t}^{p}$ \\
\hline & \multicolumn{6}{|c|}{ Panel 1: Tariff 1 (f-p weights) } \\
\hline $\log \left(1+\widetilde{\tau}_{f j t}\right)$ & $\begin{array}{r}-1.768^{a} \\
(0.160)\end{array}$ & $\begin{array}{c}-0.238^{a} \\
(0.086)\end{array}$ & $\begin{array}{r}-1.530^{a} \\
(0.143)\end{array}$ & $\begin{array}{l}-2.204^{a} \\
(0.237)\end{array}$ & $\begin{array}{r}-0.647^{a} \\
(0.118)\end{array}$ & $\begin{array}{r}-1.558^{a} \\
(0.205)\end{array}$ \\
\hline \multirow[t]{2}{*}{ Observations } & 25,816 & 25,816 & 25,816 & 11,521 & 11,521 & 11,521 \\
\hline & \multicolumn{6}{|c|}{ Panel 2: Tariff $1+$ single reference population in US and $\mathrm{j}$} \\
\hline $\log \left(1+\widetilde{\tau}_{f j t}\right)$ & $\begin{array}{l}-2.018^{a} \\
(0.160)\end{array}$ & $\begin{array}{r}-\mathbf{- 0 . 3 4 5}^{a} \\
(\mathbf{0 . 0 8 6 )})\end{array}$ & $\begin{array}{r}-1.674^{a} \\
(0.145)\end{array}$ & $\begin{array}{l}-2.479^{a} \\
(0.237)\end{array}$ & $\begin{array}{r}-0.761^{a} \\
(0.118)\end{array}$ & $\begin{array}{r}-1.718^{a} \\
(0.208)\end{array}$ \\
\hline \multirow[t]{2}{*}{ Observations } & 25,816 & 25,816 & 25,816 & 11,521 & 11,521 & 11,521 \\
\hline & \multicolumn{6}{|c|}{ Panel 3 : Tariff 2 (f-p-j weights) + single reference population in US and $j$} \\
\hline $\log \left(1+\widetilde{\tau}_{f j t}\right)$ & $\begin{array}{r}-2.140^{a} \\
(0.163)\end{array}$ & $\begin{array}{l}-0.200^{b} \\
(0.085)\end{array}$ & $\begin{array}{r}-1.940^{a} \\
(0.145)\end{array}$ & $\begin{array}{r}-2.557^{a} \\
(0.244)\end{array}$ & $\begin{array}{r}-0.570^{a} \\
(0.118)\end{array}$ & $\begin{array}{r}-1.987^{a} \\
(0.209)\end{array}$ \\
\hline Observations & 25,816 & 25,816 & 25,816 & 11,521 & 11,521 & 11,521 \\
\hline Exporters & \multicolumn{3}{|c|}{ Top 500 exporters in US market } & \multicolumn{3}{|c|}{ Top 200 exporters in US market } \\
\hline
\end{tabular}

Note: Significance levels: ${ }^{c} 10 \%,{ }^{b} 5 \%,{ }^{a} 1 \%$. Robust standard errors are clustered by firm-destination. OLS estimations. $x_{f j t}$ is the total value of exports by each firm $f$ on each destination $j$ and year $t . n_{f j t}^{p}$ is the number of products exported by firm. $\bar{x}_{f j t}^{p}$ is the average value of exports by product. Transformation of exports and tariffs: $\widetilde{z}_{f j}=\frac{z_{f j}}{z_{f, U S}} / \frac{\overline{z_{f j}}}{\overline{z_{f, U S}}}$ Reference population: Top 500 firms in each destination. Destinations: Extra EU 15 destinations, 2001, 2004 and 2007. Reference destination: United States (21\% of French extra-EU15 exports).

\section{ACCOUnTING FOR THE ADJUSTMENT OF THE PRODUCT-MiX}

The elasticity of the average value exports per product by firm $\left(\bar{x}_{f j t}^{p}\right)$ with respect to tariff variations, estimated in the previous section, is however biased by the selection of products in destination markets by the firm. Firms adjust their product mix to the accessibility of the destination: they concentrate on their core product(s) in more difficult destinations. This justifies shifting to estimations on firm-productdestination exports and concentrating on the best performing products. 


\subsection{Empirical strategy}

We now consider the case of firm-product level exports to each destination $\left(x_{f j p t}\right)$, which is the baseline unit of observation in the French customs data. A first strategy consists in replicating the transformation used above. In this case, we control for the firm unobserved characteristics summarized in its price $\pi$ as well as for the aggregate market characteristics (Equation 8).

$$
\widetilde{x}_{f j p}^{1}=\frac{x_{f j p}}{x_{\mathbf{f}, U S}} / \frac{\overline{x_{f j}}}{\overline{x_{f, U S}}}
$$

This transformation does not account, however, for the possibility that the efficiency of the firm may differ across products, which introduces a downward bias in the estimation of the trade elasticity if the best products are exported to the destinations with higher variable trade costs. To account for this possibility, a second strategy uses the ratio of firm-product exports to destination $j$ and firm-product exports to the US $\left(\frac{x_{f j p}}{x_{\mathrm{fp}_{\mathrm{p}}, U S}}\right)$, which allows us to control for product heterogeneity within the firm (9). A similar transformation is used for tariffs by product and destination $\left(\widetilde{\theta}_{j p}\right)$. In the tables below we refer to the transformed export and tariff variables using the notation $\widetilde{z}$.

$$
\widetilde{x}_{f j p}^{2}=\frac{x_{f j p}}{x_{\mathbf{f p}, U S}} / \frac{\overline{x_{f j}}}{\overline{x_{f, U S}}}
$$

\subsection{Micro estimates: firm-product level exports}

The selection of products driven by the variance in tariffs could still affect the estimated trade elasticity, through the changes in the product mix in each destination. In more difficult markets, we expect firms to concentrate on their best product(s). We must now shift to estimations on firm-product-destination exports by year. The empirical methodology developed in the previous section is used to control for the adjustment of the product mix in each destination. The benchmark destination is the US, as before. Equation (10) is estimated using an OLS estimator as in the case of firm-level exports.

$$
\log \left(\widetilde{x_{f j p t}}\right)=(1-\sigma) \log \left(\widetilde{\theta_{f j p t}}\right)+\epsilon_{f j p t}
$$

In the three first columns of Table 5, we consider the top 500 French exporters to the US, while we restrict to the 200 top ones in the next three columns. In columns (1) and (4) we consider all products exported by each firm in our sample, while we restrict observations to products jointly exported by each firm in the sample to the US and to destination $j$ in columns (2), (3), (5) and (6). The transformation used for our export and tariff variables is controlling for firms and products in columns (3) and (6), but for firms only in the other columns. Finally, the sample of exporters used as a reference population for the computation of our ratios is the top 500 French firms in the US and the 500 top exporters in each destination in panel 1 ; in contrast, we restrict in panel 2 the reference population in each destination $j$ to firms present in this destination among the 500 top exporters in the US. The comparison of panels 1 and 2 points to the importance of controlling for firm selection in our reference population in the different destinations. We keep this restriction in panels 3 and 4 .

Estimation results reported in Table 5 confirm that variable trade costs have a negative impact on firmproduct level exports in each destination. In the first two columns of the table where the exports variable is transformed without taking into account unobserved product efficiency at the firm-level (the reference used to compute the firm-product exports ratio is firm-level total exports to the US rather than firm-product-level exports to the US), the estimated elasticity is negative but quite small. As expected, controlling for the product composition of firm exports (column 3) increases the elasticity. 
The estimated elasticity is robust to restrictions to the product mix considered. We progressively concentrate on the best performing products of the firm: top 10 products in panel 2, top 3 products in panel 3 , core product in panel 4 . In the latter case, where any impact of the product mix is neutralized, we obtain an elasticity of about -2.5 . This is our preferred estimate. Concentrating on the top 200 exporters to the US would provide slightly higher elasticities. These results confirm that variable trade costs affect the product composition of firms in each destination, with multi-product exporters concentrating on their best performing varieties in more difficult destinations.

Table 5 - The effect of tariffs on individual exports values

\begin{tabular}{|c|c|c|c|c|c|c|}
\hline \multirow[b]{2}{*}{ Dep. Var. } & $\overline{(1)}$ & $\overline{(2)}$ & (3) & (4) & $\overline{(5)}$ & (6) \\
\hline & $\log \widetilde{x}_{f j p t}$ & $\log \widetilde{x}_{f j p t}$ & $\log \widetilde{x}_{f j p t}$ & $\log \widetilde{x}_{f j p t}$ & $\log \widetilde{x}_{f j p t}$ & $\log \widetilde{x}_{f j p t}$ \\
\hline \multirow[b]{2}{*}{$\log \left(1+\widetilde{\tau}_{j p t}\right)$} & & Referenc & $\begin{array}{l}\text { Panel } 1: \mathrm{T} \\
\text { opulation: } \mathrm{t}\end{array}$ & $\begin{array}{l}10 \text { products } \\
500 \text { firms in } t\end{array}$ & US and $\mathrm{j}$ & \\
\hline & $\begin{array}{r}-0.363^{a} \\
(0.104)\end{array}$ & $\begin{array}{l}-0.337^{a} \\
(0.110)\end{array}$ & $\begin{array}{r}-1.880^{a} \\
(0.140)\end{array}$ & $\begin{array}{r}-0.576^{a} \\
(0.140)\end{array}$ & $\begin{array}{r}-0.506^{a} \\
(0.147)\end{array}$ & $\begin{array}{r}-1.946^{a} \\
(0.199)\end{array}$ \\
\hline \multirow[t]{2}{*}{ Observations } & 46,420 & 42,068 & 54,460 & 25,430 & 23,435 & 28,866 \\
\hline & \multicolumn{6}{|c|}{$\begin{array}{l}\text { Panel } 2: \text { Top } 10 \text { products } \\
\text { Reference population: single reference population in US and } \mathrm{j} \text { among top } 500\end{array}$} \\
\hline $\log \left(1+\widetilde{\tau}_{j p t}\right)$ & $\begin{array}{r}-0.520^{a} \\
(0.105)\end{array}$ & $\begin{array}{r}-0.521^{a} \\
(0.111)\end{array}$ & $\begin{array}{r}-2.064^{a} \\
(0.143)\end{array}$ & $\begin{array}{r}-0.737^{a} \\
(0.142)\end{array}$ & $\begin{array}{r}-0.703^{a} \\
(0.149)\end{array}$ & $\begin{array}{r}-2.167^{a} \\
(0.205)\end{array}$ \\
\hline \multirow[t]{2}{*}{ Observations } & 46,420 & 42,068 & 54,460 & 25,430 & 23,435 & 28,866 \\
\hline & \multicolumn{6}{|c|}{$\begin{array}{l}\text { Panel } 3: \text { Top } 3 \text { products } \\
\text { Reference population : single reference population in US and } \mathrm{j} \text { among top } 500\end{array}$} \\
\hline $\log \left(1+\widetilde{\tau}_{j p t}\right)$ & $\begin{array}{r}-0.942^{a} \\
(0.122)\end{array}$ & $\begin{array}{r}-0.899^{a} \\
(0.124)\end{array}$ & $\begin{array}{l}-2.014 \\
(0.150)\end{array}$ & $\begin{array}{r}-1.277^{a} \\
(0.169)\end{array}$ & $\begin{array}{r}-1.228^{a} \\
(0.172)\end{array}$ & $\begin{array}{r}-2.451^{a} \\
(0.215)\end{array}$ \\
\hline \multirow[t]{2}{*}{ Observations } & 29,675 & 28,332 & 34,780 & 14,803 & 14,250 & 16,792 \\
\hline & \multicolumn{6}{|c|}{$\begin{array}{l}\text { Panel } 4: \text { Core product } \\
\text { Reference population: single reference population in US and j among top } 500\end{array}$} \\
\hline $\log \left(1+\widetilde{\tau}_{j p t}\right)$ & $\begin{array}{r}-1.481^{a} \\
(0.155)\end{array}$ & $\begin{array}{r}-1.403^{a} \\
(0.155)\end{array}$ & $\begin{array}{r}-2.483 \\
(\mathbf{0 . 1 5 9})\end{array}$ & $\begin{array}{r}-1.888^{a} \\
(0.217)\end{array}$ & $\begin{array}{r}-1.794^{a} \\
(0.217)\end{array}$ & $\begin{array}{r}-3.171^{a} \\
(0.236)\end{array}$ \\
\hline Observations & 14,682 & 14,429 & 17,264 & 6,928 & 6,844 & 7,928 \\
\hline Sample of products & $S_{1}$ & $S_{2}$ & $S_{2}$ & $S_{1}$ & $S_{2}$ & $S_{2}$ \\
\hline Transformation & $\widetilde{z}_{f j p}^{1}$ & $\widetilde{z}_{f j p}^{1}$ & $\widetilde{z}_{f j p}^{2}$ & $\widetilde{z}_{f j p}^{1}$ & $\widetilde{z}_{f j p}^{1}$ & $\widetilde{z}_{f j p}^{2}$ \\
\hline Exporters & \multicolumn{3}{|c|}{ Top 500 exporters in US market } & \multicolumn{3}{|c|}{ Top 200 exporters in US market } \\
\hline
\end{tabular}

Note: Significance levels: ${ }^{c} 10 \%,{ }^{b} 5 \%,{ }^{a} 1 \%$. Robust standard errors are clustered by firm-product-destination. $x_{f p j}$ is the value of the firm-product exports to destination $j$. Sample of products: $S_{1}$ : all products; $S_{2}$ : products exported to $j$ and the US. Transformation of exports and tariffs:

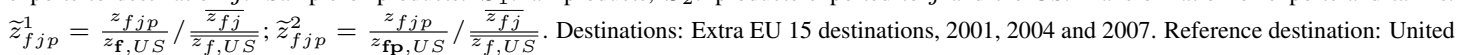
States (21\% of French extra-EU15 exports). 


\section{Conclusion.}

We use the cross sectional variation in tariffs faced by individual exporters in each destination and provide an estimation of the microeconomic elasticity of firm-level exports with respect to changes in variable trade costs, a key parameter in new trade models with heterogenous firms.

Theory warns against firm and product composition effects in presence of trade costs. We propose an empirical strategy to cope with these selection effects. A methodology of ratios is used to correct for unobserved firm characteristics driving selection in exports market as well as for the unobserved resistance term specific to each destination.

Considering French firms exporting to extra-EU destinations and focusing on the cross sectional variance in tariffs faced at the product level, we find a significant negative impact of tariffs on firm-level exports. The measured elasticity is about -2.5 when properly controlling for product composition and focusing on the core exported products. About one fifth of the impact of tariffs on exports is driven by firms adjusting their product mix across destinations.

Such elasticity can be used to calibrate welfare gains associated with tariff dismantling in a multi-product firms set up. 


\section{REFERENCES}

Albornoz, F., F., S., P., and Hallak, J. C. (2013). Survival in export markets. mimeo.

Anderson, J. E. and van Wincoop, E. (2003). Gravity with gravitas: A solution to the border puzzle. American Economic Review, 93(1):170-192.

Anderson, J. E. and van Wincoop, E. (2004). Trade costs. Journal of Economic Literature, 42(3):691751.

Arkolakis, C. and Muendler, M.-A. (2010). The extensive margin of exporting products: A firm-level analysis. NBER Working Papers 16641.

Baldwin, J. R. and Gu, W. (2004). Trade liberalization: Export-market participation, productivity growth, and innovation. Oxford Review of Economic Policy, 20(3):372-392.

Bas, M. and Bombarda, P. (2011). Unilateral trade reform, market access and foreign competition: the patterns of multi-product exporters. CEPII Working Paper 2011-18.

Bas, M., Mayer, T., and Thoenig, M. (2014). From micro to macro: demand and supply-side determinants of the trade elasticity. Mimeo Sciences Po.

Bernard, A. B., Jensen, J. B., Redding, S. J., and Schott, P. K. (2012). The Empirics of Firm Heterogeneity and International Trade. Annual Review of Economics, 4(1):283-313.

Bernard, A. B., Redding, S. J., and Schott, P. K. (2011). Multiproduct Firms and Trade Liberalization. The Quarterly Journal of Economics, 126(3):1271-1318.

Berthou, A. and Fontagné, L. (2013). How do Multiproduct Exporters React to a Change in Trade Costs? Scandinavian Journal of Economics, 115(2):326-353.

Bouet, A., Decreux, Y., Fontagne, L., Jean, S., and Laborde, D. (2008). Assessing applied protection across the world. Review of International Economics, 16(5):850-863.

Buono, I. and Lalanne, G. (2012). The effect of the uruguay round on the intensive and extensive margins of trade. Journal of International Economics, 86(2):269 - 283.

Chaney, T. (2008). Distorted gravity: The intensive and extensive margins of international trade. American Economic Review, 98(4):1707-21.

Crozet, M. and Koenig, P. (2010). Structural gravity equations with intensive and extensive margins. Canadian Journal of Economics, 43(1):41-62.

Eaton, J., Kortum, S., and Kramarz, F. (2004). Dissecting trade: Firms, industries and export destinations. American Economic Review, Papers and Proceedings, 94: 150-154.

Eckel, C. and Neary, J. P. (2010). Multi-product firms and flexible manufacturing in the global economy. Review of Economic Studies, 7(1):188-217.

Fitzgerald, D. and Haller, S. (2014). Exporters and Shocks: Dissecting the International Elasticity Puzzle. NBER Working Papers 19968.

Guimbard, H., Jean, S., Mimouni, M., and Pichot, X. (2012). Macmap-hs6 2007, an exhaustive and consistent measure of applied protection in 2007. International Economics, Q2:99-122.

Iacovone, L. and Javorcik, B. S. (2010). Multi-product exporters: Product churning, uncertainty and export discoveries*. The Economic Journal, 120(544):481-499.

Lawless, M. (2010). Deconstructing gravity: trade costs and extensive and intensive margins. Canadian Journal of Economics/Revue canadienne d'economique, 43(4):1149-1172.

Mayer, T., Melitz, M. J., and Ottaviano, G. I. P. (2014). Market Size, Competition, and the Product Mix of Exporters. American Economic Review, 104(2):495-536.

Melitz, M. J. (2003). The impact of trade on intra-industry reallocations and aggregate industry productivity. Econometrica, 71(6):1695-1725. 
Melitz, M. J. and Redding, S. J. (2013). New Trade Models, New Welfare Implications. NBER Working Papers 18919. 


\section{APPENDIX}

\subsection{Tariff data}

We provide here a description of the tariff data used. Tariffs are ad-valorem and applied: they can be considered as an accurate measure of a variable trade cost. ${ }^{21}$

The tariffs applied to France by each trade partner and for each product category are extracted from the MAcMap-HS6 database. The rationale for the construction of the database is detailed in Bouet et al. (2008). Market Access Map (MAcMap) is a database developed jointly by ITC (UNCTAD-WTO, Geneva) and CEPII (Paris). The last version is documented in Guimbard et al. (2012). It provides with a disaggregated, exhaustive and bilateral measurement of applied tariff duties, taking regional agreements and trade preferences exhaustively into account. Tariffs data are provided at the product-level with Harmonised System 6-digits detail, with a total of 5,111 product categories. The data are initially provided for the year 2001, 2004 and 2007 in the HS6-1996 revision. As the customs data are aggregated with the same level of disaggregation, our data can easily be matched after converting the products into the same revision of the HS nomenclature.

\subsection{Construction of the variable costs indicators using tariffs}

The unit of observation for the tariffs data is the tariff rate applied to French exports for product $p$ in destination $j, \tau_{j p}$. As we want to assess the effects of the variable trade costs, measured by tariffs, on the margins of French exports, we need to make some aggregation.

- The aggregate tariff faced by France in each destination $j$ has to reflect the French structure of exports by product. To avoid the endogeneity bias related to the selection of products in each destination, or the fact that tariffs will affect market shares for each product, we use a product structure for French exports that reflects the share of product $p$ in French total exports for the years 2000-2001. The following formula is applied:

$\tau_{j}=\sum_{p} \omega_{F R, p} \tau_{j p}$ with $\omega_{F R, p}=\frac{X_{F R, p}}{\sum_{p} X_{F R, p}}$ and $X_{F R, p}$ the value of French exports for product $p$.

This measure of tariff faced by France in each destination $j$ is used to explain the aggregate value of French exports to that destination, the number of transactions to that destination, and the mean value of individual transactions.

- The firm-level average tariff in each destination $j$ is computed in the same way, except that we use the product composition of firm $f$ exports in the years 2000-2001:

$\tau_{f j}=\sum_{p} \omega_{f, p} \tau_{j p}$ with $\omega_{f, p}=\frac{x_{f, p}}{\sum_{p} x_{f, p}}$ and $x_{f, p}$ the value of firm $\mathrm{f}$ exports for product $\mathrm{p}$.

Since the product structure of firm-level exports $\omega_{f, p}$ has no destination dimension, the firm-specific tariff is therefore computed by taking into account the level of tariffs in each destination, for all products that are exported at least once by the firm in the years 2000-2001.

- The tariff applied by product on French exports in destination $j, \tau_{j p}$, is used to explain the value of individual transactions when we use the most disaggregated data in the estimation.

\subsection{List of countries in firm-destination and firm-product-destination}

\subsection{Aggregate results}

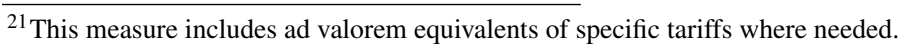


Table ST1 - List of countries used in micro-level estimations

\begin{tabular}{lcc}
\hline \hline Country & $\begin{array}{c}\text { Number of } \\
\text { observations }\end{array}$ & $\begin{array}{c}\text { Percentage of } \\
\text { observations }\end{array}$ \\
\hline United States & 1,500 & 5.81 \\
Japan & 1,197 & 4.64 \\
Canada & 1,138 & 4.41 \\
Australia & 1,100 & 4.26 \\
China & 1,075 & 4.16 \\
Korea & 1,027 & 3.98 \\
Brazil & 1,022 & 3.96 \\
Turkey & 1,014 & 3.93 \\
Singapore & 993 & 3.85 \\
Poland & 989 & 3.83 \\
South Africa & 973 & 3.77 \\
Israel & 958 & 3.71 \\
Hong Kong & 939 & 3.64 \\
Taiwan & 938 & 3.63 \\
Czech republic & 931 & 3.61 \\
Mexico & 923 & 3.58 \\
India & 874 & 3.39 \\
United Arab Emirates & 863 & 3.34 \\
Russia & 858 & 3.32 \\
Morocco & 840 & 3.25 \\
Norway & 833 & 3.23 \\
Hungary & 822 & 3.18 \\
Thailand & 802 & 3.11 \\
Tunisia & 752 & 2.91 \\
Saudi Arabia & 715 & 2.77 \\
Algeria & 587 & 2.27 \\
Lebanon & 382 & 1.48 \\
Argentina & 272 & 1.05 \\
Egypt & 253 & 0.98 \\
Malaysia & 246 & 0.95 \\
Total & 25816 & 100 \\
\hline \hline & & \\
& & \\
\hline
\end{tabular}


Table ST2 - Influence of tariffs on country-level export margins

\begin{tabular}{|c|c|c|c|c|c|c|}
\hline Dep. Var. & $\begin{array}{c}(1) \\
\log N_{j t}^{f p} \\
\end{array}$ & $\begin{array}{c}(2) \\
\log \left(\bar{X}_{j t}\right)\end{array}$ & $\begin{array}{c}(3) \\
\log \left(X_{j t}\right) \\
\end{array}$ & $\begin{array}{c}(4) \\
\log N_{j t}^{f p} \\
\end{array}$ & $\stackrel{(5)}{\log \left(\bar{X}_{j t}\right)}$ & $\begin{array}{c}(6) \\
\log \left(X_{j t}\right) \\
\end{array}$ \\
\hline $\log \left(1+\tau_{j t}\right)$ & $\begin{array}{r}-3.928^{a} \\
(0.639)\end{array}$ & $\begin{array}{c}0.726 \\
(0.562)\end{array}$ & $\begin{array}{c}-3.202^{a} \\
(0.766)\end{array}$ & $\begin{array}{r}-3.683^{a} \\
(0.631)\end{array}$ & $\begin{array}{c}0.613 \\
(0.589)\end{array}$ & $\begin{array}{c}-3.070^{a} \\
(0.778)\end{array}$ \\
\hline WTO membership $_{j t}$ & $\begin{array}{l}0.399^{a} \\
(0.086)\end{array}$ & $\begin{array}{c}-0.173^{b} \\
(0.076)\end{array}$ & $\begin{array}{l}0.226^{b} \\
(0.103)\end{array}$ & $\begin{array}{l}0.263^{a} \\
(0.087)\end{array}$ & $\begin{array}{c}-0.148^{c} \\
(0.081)\end{array}$ & $\begin{array}{c}0.115 \\
(0.107)\end{array}$ \\
\hline Log Distance $_{j}$ & $\begin{array}{r}-0.587^{a} \\
(0.056)\end{array}$ & $\begin{array}{c}0.065 \\
(0.049)\end{array}$ & $\begin{array}{c}-0.522^{a} \\
(0.067)\end{array}$ & $\begin{array}{c}-0.886^{a} \\
(0.102)\end{array}$ & $\begin{array}{c}0.135 \\
(0.095)\end{array}$ & $\begin{array}{c}-0.750^{a} \\
(0.126)\end{array}$ \\
\hline $\log$ Area $_{j}$ & $\begin{array}{r}-0.086^{a} \\
(0.023)\end{array}$ & $\begin{array}{c}-0.050^{b} \\
(0.020)\end{array}$ & $\begin{array}{c}-0.136^{a} \\
(0.027)\end{array}$ & $\begin{array}{c}-0.116^{a} \\
(0.023)\end{array}$ & $\begin{array}{c}-0.044^{b} \\
(0.021)\end{array}$ & $\begin{array}{c}-0.160^{a} \\
(0.028)\end{array}$ \\
\hline Landlocked $_{j}$ & $\begin{array}{c}-0.512^{a} \\
(0.123)\end{array}$ & $\begin{array}{c}0.171 \\
(0.108)\end{array}$ & $\begin{array}{c}-0.341^{b} \\
(0.147)\end{array}$ & $\begin{array}{c}-0.451^{a} \\
(0.116)\end{array}$ & $\begin{array}{c}0.162 \\
(0.109)\end{array}$ & $\begin{array}{c}-0.289^{b} \\
(0.144)\end{array}$ \\
\hline Common Language $_{j}$ & $\begin{array}{l}1.139^{a} \\
(0.187)\end{array}$ & $\begin{array}{c}-0.700^{a} \\
(0.164)\end{array}$ & $\begin{array}{l}0.438^{c} \\
(0.223)\end{array}$ & $\begin{array}{l}1.220^{a} \\
(0.178)\end{array}$ & $\begin{array}{c}-0.701^{a} \\
(0.166)\end{array}$ & $\begin{array}{l}0.519^{b} \\
(0.220)\end{array}$ \\
\hline Colonial link ${ }_{j}$ & $\begin{array}{l}0.842^{a} \\
(0.166)\end{array}$ & $\begin{array}{c}-0.002 \\
(0.146)\end{array}$ & $\begin{array}{l}0.840^{a} \\
(0.199)\end{array}$ & $\begin{array}{l}0.863^{a} \\
(0.158)\end{array}$ & $\begin{array}{c}-0.011 \\
(0.147)\end{array}$ & $\begin{array}{l}0.851^{a} \\
(0.194)\end{array}$ \\
\hline Common legal origin $_{j}$ & $\begin{array}{c}-0.036 \\
(0.086)\end{array}$ & $\begin{array}{l}0.288^{a} \\
(0.075)\end{array}$ & $\begin{array}{l}0.252^{b} \\
(0.103)\end{array}$ & $\begin{array}{c}-0.151^{c} \\
(0.086)\end{array}$ & $\begin{array}{l}0.313^{a} \\
(0.081)\end{array}$ & $\begin{array}{c}0.162 \\
(0.107)\end{array}$ \\
\hline $\log _{\text {real GDP }} j t$ & $\begin{array}{l}0.547^{a} \\
(0.029)\end{array}$ & $\begin{array}{l}0.272^{a} \\
(0.026)\end{array}$ & $\begin{array}{l}0.820^{a} \\
(0.035)\end{array}$ & $\begin{array}{l}0.599^{a} \\
(0.030)\end{array}$ & $\begin{array}{l}0.263^{a} \\
(0.028)\end{array}$ & $\begin{array}{l}0.862^{a} \\
(0.037)\end{array}$ \\
\hline Log Multilateral distance $_{j}$ & & & & $\begin{array}{l}1.395^{a} \\
(0.376)\end{array}$ & $\begin{array}{c}-0.309 \\
(0.351)\end{array}$ & $\begin{array}{l}1.086^{b} \\
(0.464)\end{array}$ \\
\hline $\log \left(1+\right.$ Herfindahl $\left._{j t}\right)$ & & & & $\begin{array}{c}-2.314^{a} \\
(0.592)\end{array}$ & $\begin{array}{c}0.116 \\
(0.553)\end{array}$ & $\begin{array}{c}-2.199^{a} \\
(0.730)\end{array}$ \\
\hline Time dummies & yes & yes & yes & yes & yes & yes \\
\hline Observations & 240 & 240 & 240 & 240 & 240 & 240 \\
\hline R-squared & 0.761 & 0.608 & 0.769 & 0.789 & 0.610 & 0.783 \\
\hline
\end{tabular}

Note: Significance levels: ${ }^{c} 10 \%,{ }^{b} 5 \%,{ }^{a} 1 \%$. Robust standard errors in parentheses. $N_{j t}^{f p}$ is the number of firm-product transactions to destination $j$ . $\bar{x}_{j t}^{f p}$ is the mean value of firm-product transactions to destination $j . X_{j t}$ is the aggregate value of exports to destination $j$. Sample: Extra EU 15 destinations; pooled data for years 2001, 2004 and 2007. 